\title{
Haemato-biochemical Alterations in Obstructive and Non- obstructive Renal Diseases
}

\author{
P. Gupta, H.R. Bhardwaj, A.K. Gupta, R.B. Kushwaha, A. Sharma, D.K. Dwivedi, A. Kumar
}

10.18805/IJAR.B-4729

\begin{abstract}
Background: Diseases involving urinary system are very common in dogs causing significant morbidity and mortality in dogs. Renal failure and urinary obstruction are frequently encountered in clinical cases. Early diagnosis and treatment increase the survival rate and decreases the chances of complications related to renal failure. The present study was conducted to evaluate haemato-biochemical alterations in dogs having urinary system dysfunction.

Methods: The study was conducted on 38 dogs to observe the haemato-biochemical parameter changes in dogs suffering from obstructive and non-obstructive renal system affections as compared to healthy dogs. Various haemato-biochemical parameters viz. $\mathrm{Hb}, \mathrm{PCV}, \mathrm{TEC}, \mathrm{TLC}, \mathrm{DLC}, \mathrm{BUN}$, creatinine, ALT, AST, ALP, TP, albumin and A:G ratio were evaluated. Qualitative analysis of urine was done using Multistix dip stick method.

Result: In the present study the values of various haemato-biochemical parameters showed different pattern in both obstructive and non-obstructive renal diseases. Significant haematobiochemical changes reported in renal failure dogs were anemia, azotemia, increased alkaline phosphatase and AST values and decreased A:G ratio and in dogs with urinary obstruction the significant changes were uremia and leukocytosis. The results of the study suggested that the evaluation of various haemato-biochemical parameters help in diagnosis and predicting the prognosis of a renal disease.
\end{abstract}

Key words: Dog, Haemato-biochemical, Proteinuria, Renal failure, Urinary obstruction.

\section{INTRODUCTION}

Urinary system disorders in dogs are very common and are presented as the most important clinical problem. The initial signs usually go un-noticed until and unless there is enough damage to the nephrons leading to systemic manifestation of disease or there is complete obstruction or marked change in the urination behavior of the patient. Such late presentation requires quicker diagnosis (Sarma and Kalita, 2019). A haemato-biochemical evaluation stands first in diagnostic plan and in any disease condition points towards the systemic disturbances. Changes which occur in the physical and chemical constituents of blood provide a better understanding of the disease processes and are helpful in differential diagnosis, therapy and prognostication (Kaneko et al., 2008). Earlier studies suggested that haemato-biochemical alterations can be used for diagnosis of renal insufficiency (Kandula and Karlapudi, 2015; Sumit, 2018; Devipriya et al., 2018). The most common kidney disease in dogs is chronic kidney disease (CKD), with prevalence varying from 0.05 to $3.74 \%$ (Sumit et al., 2018). Chronic kidney disease (CKD) is defined as the presence of structural or functional abnormalities of one or both the kidneys that have been present for an extended period, usually three months or longer (Polzin, 2011) or azotemia of renal origin that has been present for more than two weeks (Barber, 2003). Predisposing factors contributing for renal diseases are age, breed, body size and obesity (Devipriya et al., 2018). Polzin (2007) reported that though renal insufficiency cannot be cured completely, early diagnosis can help in symptomatic and supportive therapy to reduce consequences of renal dysfunction. Another common affection of urinary
Division of Veterinary Surgery and Radiology, Faculty of Veterinary Sciences and Animal Husbandry, Sher-e-Kashmir University Agricultural Sciences and Technology of Jammu, R.S. Pura-181 102, Jammu and Kashmir, India.

Corresponding Author: P. Gupta, Division of Veterinary Surgery and Radiology, Faculty of Veterinary Sciences and Animal Husbandry, Sher-e-Kashmir University Agricultural Sciences and Technology of Jammu, R.S. Pura-181 102, Jammu and Kashmir, India. Email: drpankaj.skuast@gmail.com

How to cite this article: Gupta, P., Bhardwaj, H.R., Gupta, A.K., Kushwaha, R.B., Sharma, A., Dwivedi, D.K., Kumar, A. (2021). Haemato-biochemical Alterations in Obstructive and Nonobstructive Renal Diseases. Indian Journal of Animal Research. DOI: 10.18805/IJAR.B-4729.

Submitted: 19-07-2021 Accepted: 13-10-2021 Online: 19-11-2021

system in dogs is urolithiasis. Urolithiasis can be defined as the formation of sediment anywhere within the urinary tract which consists of one or more poorly soluble urine crystalloids (Tion et al., 2015). Osborne et al. (1999) reported that $3 \%$ of dogs seen at veterinary hospitals are affected by urolithiasis. Cystolithiasis occurs in $0.4-2 \%$ of the canine population (Morgan, 1997) and smaller dog breeds are more prone than larger breeds (Lulich et al., 2000). The patients biochemical profile and complete blood count may be normal, however, in some cases abnormalities may suggest certain urolith type, such as association of hypercalcemia with calcium oxalate or calcium phosphate uroliths. Urine analysis is an important part of diagnostic evaluation for all urinary disorders and is of great importance since it enables us to provide early treatment and 
thereby enhance chances of recovery. Urine analysis when performed properly is a highly reliable index of renal disease (Parrah et al., 2013).

\section{MATERIALS AND METHODS}

The study included 38 dogs divided into three groups viz. Group I, II and III. Group I (control group) included six healthy dogs brought for routine checkup or vaccination, Group II included 14 dogs presented with signs of renal failure and Group III comprised of 18 dogs with signs of urinary obstruction. In all dogs, $5 \mathrm{ml}$ of venous blood was collected aseptically of which $1 \mathrm{ml}$ was used for haematological analysis and $4 \mathrm{ml}$ was centrifuged at 3000rpm for five minutes for serum separation. Haematological parameters viz. haemoglobin $(\mathrm{Hb})$, packed cell volume (PCV), total leucocyte count (TLC), total erythrocyte count (TEC) were determined using Mythic 18 vet, haematology analyzer. Differential leukocyte count (DLC) was done by standard slide method using Leishman's stain. Clotting time (CT) and bleeding time (BT) were determined by capillary tube method and toe nail bleeding method, respectively. The biochemical parameters viz. blood urea nitrogen (BUN), creatinine, alanine amino-transferase (ALT), aspartate aminotransferase (AST), alkaline Phosphatase (ALP), total protein (TP), albumin and total bilirubin were estimated using ERBA kits (Bayer Diagnostic Ltd., Baroda, India) on a chemistry analyzer (Chemistry analyser, RT 1904C KAYTO, Japan) and albumin globulin ratio $(A: G)$ was obtained by manual calculations. In all the dogs, qualitative analysis of urine was done using Siemens Multistix ${ }^{\circledR}$ dip sticks after collecting urine aseptically either by catheterization or by cystocentesis.

\section{RESULTS AND DISCUSSION}

\section{Haemato-biochemical parameters}

Haematological and biochemical parameters of Group I, II and III are given in Table 1 and Table 2, respectively. The haemato-biochemical parameters of Group I were within normal physiological limits which indicated their healthy status. The values were similar to those reported by Kaneko et al. (2008), Morgan (2008) and Porter and Kaplan (2011).

The mean of $\mathrm{Hb}, \mathrm{PCV}$ and TEC values were lowest in Group II $\left(9.09 \pm 0.79 \mathrm{~g} / \mathrm{dl}, 28.17 \pm 2.44 \%\right.$ and $\left.4.25 \pm 0.24 \times 10^{6} / \mu \mathrm{L}\right)$ followed by Group III (11.66 $\pm 0.28 \mathrm{~g} / \mathrm{dl}, 35.49 \pm 0.99 \%$ and $\left.4.85 \pm 0.14 \times 10^{6} / \mu \mathrm{L}\right)$ and Group I (12.55 $\pm 0.38 \mathrm{~g} / \mathrm{dl}, 40.00 \pm 1.19 \%$ and $5.06 \pm 0.10 \times 10^{6} / \mu \mathrm{L}$ ), respectively. The decrease in $\mathrm{Hb}$, PCV and TEC values could be due to various pathogenesis involved such as hemolysis of RBCs due to uremia, decreased survival period of RBCs (Ly et al., 2004), loss of blood in GIT as melena and haematemesis, loss from urinary tract in haematuria due to poor platelet production and due to deficiency of erythropoietin production by diseased kidneys leading to bone marrow suppression (Silverberg et al., 2002). Similar findings of lower $\mathrm{Hb}, \mathrm{PCV}$ and TEC were reported by Pradhan and Roy (2012); Sharma et al. (2015) and Sumit et al. (2018). The mean of TLC and neutrophilic count was significantly higher in Group III (15.30 $\pm 1.65 \times 10^{3} /$ $\mu \mathrm{L}$ and $75.38 \pm 1.32 \%)$ as compared to Group I $\left(7.09 \pm 0.30 \times 10^{3} / \mu \mathrm{L}\right.$ and $\left.66.62 \pm 0.90 \%\right)$ and Group II (11.98 $\pm 0.91 \times 10^{3} / \mu \mathrm{L}$ and $\left.67.86 \pm 1.85 \%\right)$. High leuckocyte count in GROUP II and Group III may be due to infection and inflammation of urinary tract. Leuckocytosis observed in affected dogs was in agreement with Osborne et al. (1972) and Robinson et al. (1989).

The mean of BUN and creatinine was significantly higher in Group II $(146.16 \pm 8.83 \mathrm{mg} / \mathrm{dl}$ and $8.72 \pm 1.60 \mathrm{mg} /$ dl) as compared to Group I (16.56 \pm 2.63 and 3.18 \pm 0.84$)$ and Group III (44.79 \pm 26.97 and $0.95 \pm 0.14)$. Increase in urea and creatinine levels in renal failure might be due to marked reduction in glomerular filtration rate, diminished renal excretion, enhanced tubular absorption of urea and impaired ability of kidneys to excrete proteinaceouscatabolites. Similar findings of increased BUN and creatinine values in renal failure have been reported by other workers (Patil, 2011; Kumar, 2013; Puri et al., 2015; Devipriya et al., 2018 and Sumit et al., 2018). Increased mean values of BUN in Group III could be due increased tubular absorption and decreased elimination of urea because of obstruction. Sarma and Kalita (2019) also reported that BUN, serum creatinine and alkaline phosphatase are ideal indicators for detection of any abnormalities in urinary system. The mean AST and ALP values of Group II $(67.19 \pm 24.69$ and $134.24 \pm 33.07)$ were higher than that of Group I $(22.15 \pm 3.39$ and $33.60 \pm 3.87)$ and Group III (35.07 \pm 8.87 and 68.76 \pm 13.53$)$. In dogs, AST is less specific liver enzyme as there are high levels both in skeletal muscles and red blood cells (Richter, 2004) and the increase in AST value in renal failure might be due to loss of skeletal muscle mass and increased haemolysis, a result of CKD. Increase in AST value in CKD have also been reported by earlier workers (Pradhan and Roy, 2012; Carrero

Table 1: Mean \pm SEM of haematological parameters of Group I, Group II and Group III.

\begin{tabular}{|c|c|c|c|c|c|c|c|c|c|}
\hline Group & $\mathrm{Hb}(\mathrm{g} / \mathrm{dl})$ & $\operatorname{TLC}\left(\times 10^{3} / \mu \mathrm{L}\right)$ & $\mathrm{N}(\%)$ & $\mathrm{L}(\%)$ & $\mathrm{O}^{*}(\%)$ & PCV (\%) & TEC $\left(\times 10^{6} / \mu \mathrm{L}\right)$ & BT (Min) & CT (Min) \\
\hline I & 12.55 & 7.09 & 66.62 & 28.20 & 5.183 & 40.00 & 5.06 & 1.62 & 3.83 \\
\hline$(n=6)$ & $\pm 0.32^{b}$ & $\pm 0.30^{a}$ & $\pm 0.90^{\mathrm{a}}$ & $\pm 0.59^{b}$ & \pm 0.53 & $\pm 1.19^{b}$ & $\pm 0.10^{\mathrm{b}}$ & \pm 0.12 & \pm 0.24 \\
\hline II & 9.09 & 11.98 & 67.86 & 26.21 & 5.64 & 28.17 & 4.25 & 1.60 & 3.95 \\
\hline$(n=14)$ & $\pm 0.79^{a}$ & $\pm 0.91^{a b}$ & $\pm 1.85^{\mathrm{a}}$ & $\pm 1.17^{b}$ & \pm 0.86 & $\pm 2.44^{\mathrm{a}}$ & $\pm 0.24^{\mathrm{a}}$ & \pm 0.11 & \pm 0.20 \\
\hline III & 11.66 & 15.30 & 75.38 & 20.51 & 4.05 & 35.49 & 4.85 & 1.48 & 3.50 \\
\hline$(\mathrm{n}=18)$ & $\pm 0.28^{b}$ & $\pm 1.65^{\mathrm{b}}$ & $\pm 1.32^{\mathrm{b}}$ & $\pm 1.19^{\mathrm{a}}$ & \pm 0.39 & $\pm 0.99^{b}$ & $\pm 0.14^{b}$ & \pm 0.13 & \pm 0.19 \\
\hline
\end{tabular}

Mean \pm SEM values with different superscript differ significantly between the groups $(\mathrm{P}<0.05)$. ${ }^{*} \mathrm{O}$ Others including Monocytes, basophils and Eosinophils. 
Haemato-biochemical Alterations in Obstructive and Non-obstructive Renal Diseases

Table 2: Mean \pm SEM of various biochemical parameters of Group I, Group II and Group III.

\begin{tabular}{lccccccccc}
\hline Groups & $\mathrm{BUN}(\mathrm{mg} / \mathrm{dL})$ & $\mathrm{CRTN}(\mathrm{mg} / \mathrm{dL})$ & ALT $(\mathrm{U} / \mathrm{L})$ & AST $(\mathrm{U} / \mathrm{L})$ & AP $(\mathrm{U} / \mathrm{L})$ & $\mathrm{TP}(\mathrm{g} / \mathrm{dL})$ & ALB $(\mathrm{g} / \mathrm{dL})$ & $\mathrm{A}: \mathrm{G}$ ratio $\mathrm{TB}(\mathrm{mg} / \mathrm{dL})$ \\
\hline $\mathrm{I}$ & $16.56 \pm$ & $0.95 \pm$ & $15.17 \pm$ & $22.15 \pm$ & 33.60 & $6.26 \pm$ & $3.68 \pm$ & $1.38 \pm$ & $0.49 \pm$ \\
$\mathrm{n}=6$ & $2.63^{\mathrm{a}}$ & $0.14^{\mathrm{a}}$ & 1.84 & 3.39 & $\pm 3.87^{\mathrm{a}}$ & 0.21 & 0.17 & $0.12^{\mathrm{b}}$ & 0.06 \\
$\mathrm{II}$ & $146.16 \pm$ & $8.72 \pm$ & 34.52 & $67.19 \pm$ & $134.24 \pm$ & $6.97 \pm$ & $2.99 \pm$ & $0.81 \pm$ & $0.55 \pm$ \\
$\mathrm{n}=14$ & $8.83^{\mathrm{b}}$ & $1.60^{\mathrm{b}}$ & \pm 6.18 & 24.69 & $33.07^{\mathrm{b}}$ & 0.37 & 0.30 & $0.09^{\mathrm{a}}$ & 0.14 \\
$\mathrm{III}$ & $44.79 \pm$ & $3.18 \pm$ & 28.38 & $35.07 \pm$ & $68.76 \pm$ & $6.20 \pm$ & $3.03 \pm$ & $1.03 \pm$ & $0.49 \pm$ \\
$\mathrm{n}=18$ & $26.97^{\mathrm{a}}$ & $0.84^{\mathrm{a}}$ & \pm 5.68 & 8.87 & $13.53^{\mathrm{ab}}$ & 0.47 & 0.23 & $0.11^{\mathrm{ab}}$ & 0.10 \\
\hline
\end{tabular}

Mean \pm SEM values with different superscript differ significantly between the groups $(P<0.05)$.

et al., 2016; Sumit et al., 2018). Increased ALP in renal failure might be due to secondary renal parathyroidism, which has been reported to be associated with increased mortality in chronic renal failure dogs (Beddhu et al., 2009). Many earlier workers had also reported elevated serum ALP in dogs suffering from CKD (Ross et al., 2007; Kumar, 2013 and Sumit et al., 2018). There was no significant difference in TP and ALB values between any groups, however the lowest albumin values were recorded in Group II (2.99 \pm 0.30$)$ followed by Group III (3.03 \pm 0.23$)$ and Group I (3.68 \pm 0.17$)$. The A: $G$ ratio was significantly lower in Group II (0.81 \pm 0.09$)$ as compared to Group I $(1.38 \pm 0.12)$, however there was non-significant difference between Group I (1.38 \pm 0.12$)$ and Group III (1.03 \pm 0.11$)$. The decreased A:G ratio might be due to hypoalbuminemia due to gastrointestinal or renal protein loss of albumin and increased globulin levels in renal failure. Similar findings were also observed by Pradhan and Roy (2012) and Sumit et al. (2018). High values of globulin might be the reason for normal levels of protein observed in the present study. Girishkumar et al. (2011) conducted a study on chronic renal failure and found that there was reduced level of albumin in serum of dog with chronic renal failure. Decreased production and increased loss of albumin during inflammation was responsible for mild hypoalbuminemia which might be accompanied by normal or even elevated serum globulin concentrations (Throop and Cohn, 2004 and Fransson et al., 2007). The progress of infection is usually associated with marked changes in the serum proteins, production of acute phase proteins (APPs) by liver and most of the APPs are globulins (Kaneko et al., 2008). The concurrent infection might be the reason for increased globulin and total protein level. Similar findings were also observed by Pradhan and Roy (2012) and Sumit et al. (2018), whereas, Kandula and Karlapudi (2014) reported hypoproteinemia and hypoalbuminemia in dogs with CKD.

\section{Urinalysis}

Colour of urine in healthy dogs was normal, however in diseased animals colour varied from light yellow, dark yellow, red and brown to muddy brown. Light yellow colour indicates diluted urine with low specific gravity which is common in CKD. Brown colour of urine indicates mixing of blood in urine which could be due to haematuria or nephritis and red colour of urine indicates haematuria which could be due to injury caused by calculi (Kannan and Lawrence, 2010). Blood and leucocytes were present in $60 \%$ of dogs having calculi, whereas only $30 \%$ of cases with renal failure had leucocytes in urine. Presence of blood and leucocytes in urine in Group III indicates infection and mucosal irritation/ mucosal injury in cases of calculi. Glucose, ketone bodies, urobilinogen and nitrite were not seen in any group. The $\mathrm{pH}$ and specific gravity of urine in Group I, II and III were $6.25 \pm 0.52,1.024 \pm 0.0058 ; 6.41 \pm 0.64,1.018 \pm 0.0069$; and $6.85 \pm 0.65,1.021 \pm 0.0102$; respectively. Although there was no significant difference in $\mathrm{pH}$ and specific gravity between the groups, however the lowest specific gravity was recorded in renal failure group (Group II) indicting inability of kidneys to concentrate urine. These findings were similar to Kumar et al. (2011) who reported isosthenuria with significant azotemia in end stage kidney disease which might be related to malfunctioning of more than $2 / 3^{\text {rd }}$ of nephrons. Protein was absent in Group I, whereas protein was significantly higher in Group II (177.78 \pm 27.78$)$ as compared to Group III (73.75 \pm 12.80$)$. Highest protein concentration in Group II indictates glomerular leakage of proteins in renal failure cases. Proteinuria in Group III may be because of infection and inflammation of urinary tract as reported by Nagy (2009).

\section{CONCLUSION}

In the present study the significant haemato-biochemical changes reported in renal failure dogs were anemia, azotemia, increased alkaline phosphatase and AST values and decreased $A: G$ ratio, whereas in dogs with urinary obstruction the significant changes were uremia and leukocytosis. Thus the present study concluded that the evaluation of various hemato-biochemical parameters help in making early diagnosis and also in predicting the prognosis of a renal disease.

\section{ACKNOWLEDGEMENT}

Authors are extremely grateful to head, Veterinary Referral Complex, F.V. Sc and A.H for providing the necessary facilities for conducting the research work.

\section{REFERENCES}

Barber, P. (2003). Diagnosis and management of chronic renal failure in the cat. In Practice. 25: 306-313.

Beddhu, S., Ma, X., Baird, B., Cheung, A.K. and Greene, T. (2009). Serum alkaline Phosphatase and mortality in African Americans with chronic kidney disease. Clinical Journal of American Society of Nephrology. 4(11): 1805-1810. 
Carrero, J.J., Johansen, K.L., Lindholm, B., Stenvinkel, P., Cuppari, L. and Avesani, C.M. (2016). Screening for muscle wasting and dysfunction in patients with chronic kidney disease. Kidney International. 90 (1): 53-66.

Devipriya, K., Lavanya, C., Selvaraj, P. and Napolean, R.E. (2018). Early diagnosis of renal insufficiency in dogs with haemato: biochemical findings. Journal of Entomology and Zoology Studies. 6(5): 703-705.

Fransson, B.A., Lagerstedt, A.S., Bergstrom, A., Hagman, R., Chew, B.P. and Ragle, C.A. (2007). C-reactive protein, tumor necrosis factor alpha and interleukin- 6 in dogs with pyometra and SIRS. Journal of Veterinary Emergency and Critical Care. 17: 373-81.

Girishkumar, V.K., Srinivasan, S.R. and Nambi, A.P. (2011). Clinicopathological Assessment of Canine Renal Failure. Indian Veterinary Journal. 88 (7): 34-36.

Kandula, S. and Karalapudi, S.K. (2014). Prevalence of renal disorders in dogs- a clinical study. International Journal of Agricultural Sciences and Veterinary Medicine. 2(3): 146-148.

Kandula, S. and Karlapudi, S.K. (2015). Haemato-biochemical changes in dogs with renal insufficiency and its diagnostic significance. Animal Science Reporter. 9(4): 156-160.

Kaneko, J.J., Harvey, J. and Bruss, M.L. (2008). Serum Proteins and Dysproteinemias. In: Clinical Biochemistry of Domestic Dogs. [(Eds) Jiro Kaneko, John Harvey and Michael Bruss,] Academic press, New York. 6 ${ }^{\text {th }}$ edn. pp 113-17.

Kannan, K.V.A. and Lawrence, K.E. (2010). Obstructive urolithiasis in a Saanen goat in New Zealand, resulting in a ruptured bladder. Newzealand Veterinary Journal. 58(5): 269271.

Kumar, M. (2013). Studies on urinary tract disorders in dogs in Jammu. A thesis submitted to Division of Veterinary Medicine. Sher-E-Kashmir University of Agricultural Sciences and Technology of Jammu, main campus, Chatha, Jammu180009.

Kumar, V., Kumar, A. and Varshney, A.C. (2011). Ultrasonographic imaging for structural characterization of renal affections and diagnosis of associated chronic renal failure in 10 dogs. International Scholarly Research Network, ISRN Veterinary Science. Article ID 901713.

Lulich, J.P., Osborne, C.A. and Bartges, J.W. (2000). Canine lower urinary tract disorders. In: Ettinger S.J., Feldman E.C., Textbook of Veterinary Internal Medicine Diseases of the Dog and Cat. Philadelphia: WB Suanders Co. (eds) $5^{\text {th }}$ ed., pp. 1747-1781.

Ly, J., Marticorena, R. and Donnelly, S. (2004). Red blood cell survival in chronic renal failure. Americal Journal of Kidney Diseases. 44(4): 715-719.

Morgan, R.V. (1997). Urolithiasis; In Handbook of Small Animal Practice. $3^{\text {rd }}$ edition, pp. 531-541, W.B.Saunders, Philadelphia, USA.

Morgan, R.V. (2008). Appendix I - Normal Physiological Values. In: Handbook of Small Animal Practice, $5^{\text {th }}$ edn., Saunders Elsevier, St. Louis Missouri, USA. pp 1269-1273.

Nagy, D.W. (2009). Urolithiasis in small ruminants-Proceedings on Animal feed Resources, CVC in Kansas City.

Osborne, C.A., Low, D.G. and Finco, D.R. (1972). Canine and feline urology. pp 3-10. W.B. Saunders Company, Philadelphia.
Osborne, C.A., Lulich, J.P., Polzin, D.J., Allen, T.A., Kruger, J.M., et al. (1999). Medical dissolution and prevention of canine struviteurolithiasis: twenty years of experience. Veterinary Clinics of North America Small Animal Practice. 29: 73-112.

Parrah, J.D., Moulvi, B.A., Mohsin, A.G., Makhdoomi, D.M., Ather,H., Din, M.U., Dar, S. and Mir, A.Q. (2013). Importance of urinalysis in veterinary practice- A Review. Veterinary World. 6(9): 640-646.

Patil, S.B. (2011). Therapeutic management of canine azotemia with haemodialysis and evaluation of hemodialyser clearance. Thesis submitted to Bombay Veterinary College Mumbai, Maharashtra Animal and Fishery Sciences University, Nagpur (India).

Polzin, D.J. (2007). 11 guidelines for conservatively treating chronic kidney disease. Veterinary Medicine. 102: 788-799.

Polzin, D.J. (2011). Chronic kidney disease in small animals. Veterinary Clinics of North America-Small Animal Practice, 41(1): 15-30.

Porter, R.S. and Kaplan, J.L. (2011). The Merck Manual of Diagnosis and Therapy. 19th ed. Whitehouse Station, N.J.: Merck Sharp and Dohme Corp.

Pradhan, N.R. and Roy, S. (2012). Chronic renal failure in dogs and its management. Indian Journal of Canine Practice. 4(2): 88-92.

Puri, D., Dua, K., Sood, N.K., Randhawa, S. and Dhaliwal, P.S. (2015). Study of renal function in geriatric dogs. Veterinary Practitioner. 16(1): 44-46.

Richter, K. (2004). Current evaluation of liver disease (VET-194). In Western Veterinary Conference.

Robinson, W. F., Shaw, S. E., Stanley, B., Huxtable, C.R., Watson, A.D.J., Friend, S.E. and Mitten, R. (1989). Chronic renal disease in Bull terriers. Australian Veterinary Journal. 66(7): 193-195.

Ross, S.J., Osborne, C.A. and Lekcharoensuk, C. (2007). A casecontrol study of the effects of nephrolithiasis in cats with chronic kidney disease. Journal of the American Veterinary Medical Association. 230: 1854-1859.

Sarma, B.K. and Kalita, D. (2019). Changes of haematological and biochemical parameters of canine having urinary system disorders. International Journal of Chemical Studies, 7(1): 501-504.

Sharma, A., Ahuja, A., Srivastava, M. and Kachhawa, J. P. (2015). Haemato-biochemical changes in dogs suffering from chronic renal failure. Indian Journal of Canine Practice. 7(2): 102-107.

Silverberg, D.S., Wexler, D. and Blum, M. (2002). The correction of anaemia in severe resistant heart failure with erythropoietin and intravenous iron prevents the progression of both the heart and renal failure and markedly reduce hospitalization. Clinical Nephrology. 85(1): 37-45.

Sumit, Goel, P., Kumar, P., Gulia, D., Jhambh, R., Sindhu, N. and Chaudhary, R.N. (2018). Haemato-biochemical and serum electrolytes alteration in dogs with chronic kidney disease. The Pharma Innovation Journal. 7(11): 302-306.

Tion, M.T., Dvorska, J. and Saganuwan, S.A. (2015). A review on urolithiasis in dogs and cats. Bulgarian Journal of Veterinary Medicine, 18 (1): 1-18.

Throop, J.L. K.M. and Cohn, L.A. (2004). Albumin in health and disease: causes and treatment of hypoalbuminemia. Compendium. 26: 940-949. 